\section{The role of empiric embolization in diverticular bleeding}

A 90-year-old man presented with painless, fresh rectal bleeding, but was otherwise asymptomatic. Examination was normal except for the fresh blood on rectal examination. He had undergone colonoscopy for a previous episode of bleeding, which had shown only diverticulosis and no treatment had been required. His colonoscopy on admission showed diverticulosis without active bleeding. After a recurrence of his bleeding, he underwent small-intestinal enteroscopy, which was negative, but a further colonoscopy revealed two bleeding sigmoid diverticula and five endoclips were placed ( $\bullet$ Fig. 1 ). This initially secured hemostasis but he had another recurrence 2 days later. This time he underwent a ${ }^{99 \mathrm{~m} T c-l a b e l e d ~ r e d ~}$ cell scan, which was also negative.

The patient refused to undergo a colectomy but subsequently had another episode of bleeding. On this occasion arteriography was unsuccessful despite positive red blood cell scanning. The patient still refused surgery but did agree to undergo empirical embolization of the artery supplying the general region in which the endoclips had been placed. Following this procedure, the patient had an uneventful course and, to date, he has had no further episodes of bleeding.

The annual incidence of lower gastrointestinal hemorrhage is around 20.5 per 100000 , with the major cause being colonic diverticular bleeding [1]. The incidence of recurrence is $13.8 \%$ [2], with the risks being much higher in the elderly [3]. Red blood cell scanning and arteriography detect active gastrointestinal bleeding when the rates of blood loss are $>0.2 \mathrm{~mL} / \mathrm{min}$ and $>0.5-1 \mathrm{~mL} / \mathrm{min}$, respectively, so will be negative if the rate of bleeding is slow. The diagnostic sensitivity is estimated at approximately $55 \%$ for red blood cell scans [4-7]; $77 \%$ and $41 \%$ for arteriography in cases of massive [8] and any bleeding [9], respectively; $29 \%$ for arteriography after provoking an occult bleeding site [10]; and $72 \%$ for colonoscopy [11].

Surgical intervention for recurrent diverticular bleeding was almost 97\% [3]. Colectomy, the current definitive therapy, is unacceptable for many patients who will not consider having an ileostomy bag or are not suitable candidates for such surgery. Emergency colectomies have a $15 \%$ mortality rate [12].

We propose colonoscopy to identify the source and the placement of endoclips, which can also as a marker. Should therapeutic failure of the endoclips occur, empiric embolization of the artery supplying the region can then be performed. While this is not a routine procedure, we have successfully treated one patient in this way and it promises to be a possible solution for patients refusing, or unsuitable for, surgery that would have a drastic effect on their quality of life.

\section{Endoscopy_UCTN_Code_TTT_1AQ_2AZ}

\section{Competing interests: None}

\section{Chidambaram Sunder Valliappan,} Ali Kazemi, Michael Babich

Department of Gastroenterology, Allegheny General Hospital, Pittsburgh, Pennsylvania, USA

\section{References}

1 Longstreth GF. Epidemiology and outcome of patients hospitalized with acute lower GI hemorrhage: a population-based study. Am J Gastroenterol 1997; 5: 189

2 Poncet G, Heluwaert F, Voirin D et al. Natural history of acute colonic diverticular bleeding: a prospective study in 133 consecutive patients. Aliment Pharmacol Ther 2010; 32: $466-471$

3 Aytac E, Stocchi L, Gorgun E et al. Risk of recurrence and long-term outcomes after colonic diverticular bleeding. Int J Colorectal Dis 2014; 29: $373-378$

4 Olds GD, Cooper GS, Chak A et al. The yield of bleeding scans in acute lower gastrointestinal hemorrhage. J Clin Gastroenterol 2005; 39: $273-277$

5 Tabibian JH, Wong Kee Song LM, Enders FB et al. Technetium-labeled erythrocyte scintigraphy in acute gastrointestinal bleeding. Int J Colorectal Dis 2013; 28: 1099 - 1105

6 Howarth DM, Tang K, Lees W. The clinical utility of nuclear medicine imaging for the detection of occult gastrointestinal haemorrhage. Nucl Med Commun 2002; 23: 591 594

7 Bentley DE, Richardson JD. The role of tagged red blood cell imaging in the localization of gastrointestinal bleeding. Arch Surg 1991; 126: 821 - 824

8 Browder W, Cerise EJ, Litwin MS. Impact of emergency angiography in massive lower gastrointestinal bleeding. Ann Surg 1986; 204: $530-536$

9 Colacchio TA, Forde KA, Patsos TJ et al. Impact of modern diagnostic methods on the management of active rectal bleeding. Ten year experience. Am J Surg 1982; 143: 607 -610

10 Bloomfeld RS, Smith TP, Schneider AM et al. Provocative angiography in patients with gastrointestinal hemorrhage of obscure origin. Am J Gastroenterol 2000; 95: $2807-$ 2812
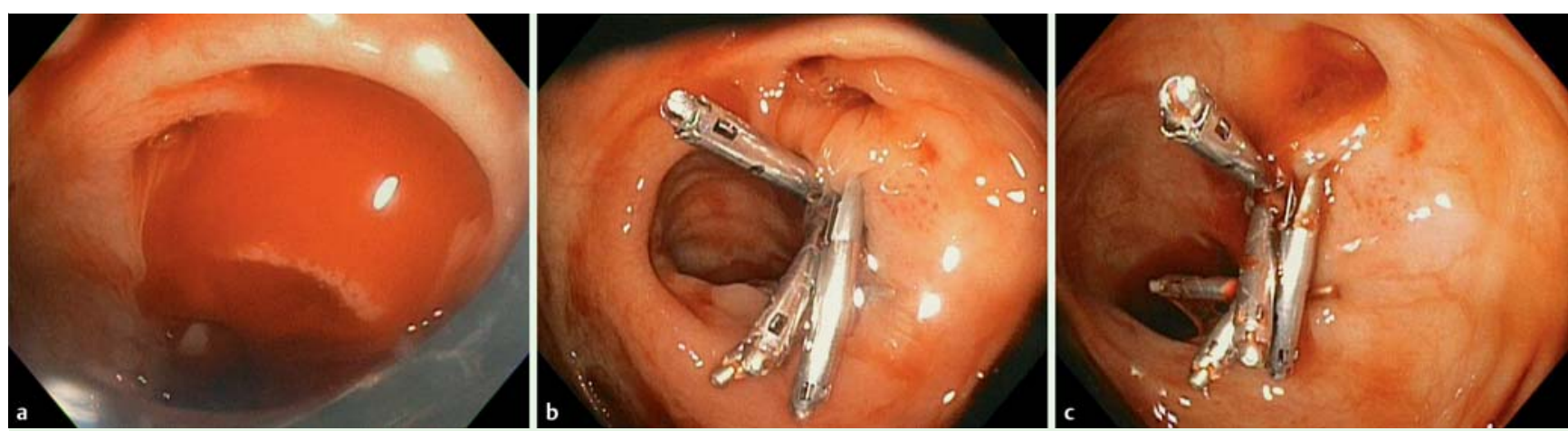

Fig. 1 Endoscopic image showing: $\mathbf{a}$ an actively bleeding diverticulum in the sigmoid colon; $\mathbf{b}$ three endoclips positioned on the diverticulum, but evidence of ongoing bleeding at a slow rate from a second diverticulum; c two further endoclips positioned at the second site, which secured complete hemostasis. 
11 Caos A, Benner KG, Manier J et al. Colonoscopy after Golytely preparation in acute rectal bleeding. J Clin Gastroenterol 1986; 8: 46-49

12 McGillicuddy EA, Schuster KM, Davis KA et al. Factors predicting morbidity and mortality in emergency colorectal procedures in elderly patients. Arch Surg 2009; 144: 1157-1162

\section{Bibliography}

Dol http://dx.doi.org/

10.1055/s-0034-1391829

Endoscopy 2015; 47: E219-E220

(c) Georg Thieme Verlag KG

Stuttgart · New York

ISSN 0013-726X

\section{Corresponding author}

Chidambaram Sunder Valliappan, MB, BS

St Isabel's Hospital - General Medicine

Oliver Road

Chennai

Tamil Nadu 600004

India

sundervalliappan@gmail.com 